\title{
Efforts to Eradicate Corruption in Indonesia's Local Government Environment
}

\author{
Rita Susanti ${ }^{1}$ \\ \{rita.susanti1412@gmail.com ${ }^{1}$ \} \\ Universitas Lampung, Lampung, Indonesia ${ }^{1}$
}

\begin{abstract}
Indonesia is still suffering as a result of the seemingly endless rise in corruption crimes, various efforts have been made to eradicate and punish the perpetrators of corruption crimes in the local government, people's concern about corruption and the attempted sentencing of regional heads who become perpetrators of corruption crimes became the focus of this research. The Research Method uses primary ingredients and secondary materials to answer the problems that have been formulated.
\end{abstract}

Keywords: corruption, crime, local government

\section{Introduction}

The current government is very driven by the problem of covic-19 which somehow ends, the budget of funds that continues to be given to health workers seems endless, on the other hand the entire Indonesian community is experiencing a difficult economic situation as a result of the covic-19 pandemic is not without reason millions of workers throughout Indonesia are very forced to accept mass layoffs due to the company in which they work in bankruptcy. Some regions in Indonesia to implement the PSBB system because of the surge in victims are increasingly falling, On the other hand the number of corruption crimes seems to be increasing, especially in the territory of local government, local officials who stumble on corruption cases as if dancing on the suffering of their people, this raises negative stigma and loss of public trust in its own leader, not uncommon for the swearing and swearing out aimed at those caught doing the hand of corruption crimes , moreover, the faces of the perpetrators who do not appear guilty of doing the act, they instead spread a big smile in front of the mass media spotlight. The mushrooming of corruption crimes is like an endless outbreak of covic19 even though it is eradicated to its root.

To know the understanding of corruption crimes can be seen the provisions of Article 2 paragraph (1) of the Law of the Republic of Indonesia No. 31 of 1999 j.o Law of the Republic of Indonesia No. 20 of 2001 on the Eradication of Corruption Crimes which states that any person who unlawfully commits an act of enriching themselves or others or a corporation that may harm the state's finances or the economy of the State, sentenced to a maximum prison sentence of 4 (four) years and a maximum of 20 (twenty) years and a maximum fine of Rp. 200,000,000.00 (two hundred million rupiah) and at most Rp. 1000,000,000.00 (one billion rupiah).

The explanation based on the above article provides an understanding of the criminal acts of corruption that are actions aimed at enriching themselves or others or corporately or individuals unlawfully and such actions may harm the State's finances. This Tipikor Act can 
reach various modus operandi of state financial irregularities or the state economy yanzg growing its crime mode.

Corruption itself is like not looking at one's strata in the system of government ranging from executive, judicial, and legislative institutions. Therefore, corruption eradication efforts should be part of the government's focus on the current declining economy, government assistance for people affected by covic-19 should be closely monitored lest funds that should be received by underprised people be abused by those who are greedy about wealth.

Corruption Eradication Commission and The Prosecutor's Office of the Republic of Indonesia as a trusted institution in dealing with corruption cases will not mean without the support of the wider community, Efforts have been taken, both to prevent and eradicate corruption crimes. Although the crime of corruption is considered an exceptional criminal case, until now none of the perpetrators of corruption crimes have been sentenced to death. Based on his understanding of corruption is interpreted as an act of bribery or receiving some money for something that has been done. According to The lexion Webster Dictionary corruption has meanings of decay, evil, depravity, dishonesty, can be bribed, immoral, deviations from chastity, derogatory or defamatory words or utterances [3]

Some of the reasons that make corruption in this country will never be exhausted due to several factors as stated by the opinion of Abdullah Hehamahua, among others are:

a. Erroneous State Maintenance System

As a developing country, the government should be focused on the development sector in the field of education. But so far the move made only to the development in the field of economic decision struck has been a long time since the era of the old order. Whereas every country that is still developing, limited in having quality human resources, money, management, and technology. As a result, all are brought from abroad which, in turn, results in a second cause of corruption.

b. Low Civil Servant Compensation

It is natural that Indonesia as a developing country does not have enough budget in terms of pay large compensation to all its employees instead of the existing budget is diverted to development in the economic sector. thus physically giving birth to a pattern of consumerism, so that most civil servants do KKN. Both in the form of time corruption, pungli activities and small-scale corruption in order to balance income and personal expenses.

c. Greedy Office

The excessive lifestyle born by the above development system encourages officials to choose to take actions outside the limits of authority so as to commit an unlawful act by choosing an act of corruption. There was a greedy attitude in which officials abused their authority and position, boycotted development projects, even did business with entrepreneurs, both in the form of being commissioners and being one of the leaders of the company.

d. Law Enforcement Does Not Run

As a result of the emergence of greedy nature both from all the lower strata groups to the upper reaches of various government agencies to the public institutions all problems are assessed in terms of money where it appears the presumption of bringing everything will be completed when tucked away with money. Even for them money is his god.

e. Ineffective Surveillance

In modern management system there is always an internal instrument of in-build control in each work unit, so that the slightest deviation will be detected early on and automatically repaired. Internal control in each unit does not work because the relevant 
officers or employees are KKN. Some information in many mass media, to overcome it was formed Irjen and Bawasda who are in charge of conducting internal audits.

f. No Exemplary Leader

When Indonesia went into economic recession none of the country's leaders set an example of being able to live in a simplicity that should be able to make its people not experience a sense of despair, unlike any other country where a leader can be a good daulan to dare to step into the middle of life away from luxury so that the moral and material support of every society is born.

g. Conducive Community Culture of KKN

In a country that is low on the quality of human resources people in Indonesia tend to do something on the basis of what they see, such as doing driver's license, ID card, registration, even until applying to school or university is done with $\mathrm{KKN}$ because local officials even like religious leaders do and give such examples[3]

As the system of governance in an area can be said to be left behind sometimes there are many problems that must be faced when making a policy and a program of governance system order. Because in making management practices must have a broad dimension so that certain aspects must be corrected first[4]

Corruption in this country seems to be common and reasonable for officials and employees who have often asked for compensation for their services when it is an obligation for them to serve the community as a form of mandate responsibility that they are undergoing. Based on the description of the discussion, this study will examine several issues including: 1 . What is the role of society in eradicating corruption in local government? 2. How does the Judge's Ruling Punish the Perpetrators of Corruption in The Local Government?. The efforts of anti-corruption institutions such as the KPK to eradicate corruption and the rise of corruption crimes make writers feel interested in writing this scientific work.

\section{Literatur Review}

Various efforts have been made by the KPK and the Indonesian Prosecutor's Office as law enforcement officials in eradicating corruption crimes both in the central government environment and even to the local government system, as has recently occurred in some districts where some village chiefs have had to deal with the law due to misappropriation of village funds. The government's efforts to optimize the eradication of corruption have been carried out since the era of leader Susilo Bambang Yudhiyono who at this time SBY as president published Presidential Instruction No. 2 of 2014 "on Prevention and Eradication of Corruption", previously the President has also issued a number of instructions and directives to prevent and eradicate corruption. The instructions include Presidential Instruction (Inpres) No. 5/2004 on Accelerating The Eradication of Corruption, Inpres No. 9/2011 on Corruption Prevention and Eradication Action year 2011, Inpres No. 17/2012 on Corruption Prevention and Eradication Action year 2012, and Inpres No. 1 of 2013 on Corruption Prevention and Eradication Action year 2013. In addition, President SBY has also issued Presidential Regulation No. 55/2012 on National Strategy for Prevention and Eradication of Long-Term Corruption in 2012-2025 and Medium Term year 2012-2014[5]

Based on historical data from 2004-2019 the KPK and the Prosecutor's Office have arrested and completed as many as 114 regional heads, namely 17 governors, 74 regents, as well as 23 mayors, that number will increase even higher considering that in 2019-2020 there 
has been a hand-catch operation that dragged several regional heads, various stigmas began to emerge from the alleged background of the perpetrators of corruption until now due to the alleged large covic-19 outbreak relief fund[1]Along with the implementation of the regional autonomy program, hope also emerged from the community about the welfare of the quality of public services provided. The community's response to being active in public policy making seems to be not responded to by local and central governments. Since the enactment of Law No. 22 of 1999 on Local Government and Law No. 25 of 1999 on Financial Balance between Central and Local Governments since January 2001, there has not been a fact that the expectations of the community have become real[1]

In an era of decentralized transition of prevailing authority that raises new problems that make various irregularities of abuse of power, corruption collusion and nepotism. The most common case of money political games in regional elections, as well as misappropriation of local revenue and expenditure budgets (APBD), highlights that there is clearly no attempt to side with the community. The number of agencies that bring up budget disaloction. As well as the levy through local regulations that clearly burden the community and is not conducive to economic development in the region[1]

Looking at and reviewing existing legislation and the rise of corruption crimes in Indonesia is not very appropriate if the perpetrators are sentenced lightly even in cases of corruption that cost the country tens of billions to be punished more lightly than someone who only steals rice to survive, refers to the written articles and laws and has the freedom to determine the punishment should the judge be appropriate to impose the death penalty for the perpetrators of corruption[2] as for the reason for the reinforcement of the statement can be seen in the following articles: the first, article 2 of Law No. 31 of 1999 jo Law No.20 of 2001 on the eradication of corruption crimes, which reads as follows:

1. Any person who unlawfully commits an act of enriching himself or another person or a corporation that may harm the state's finances or the country's economy, sentenced to life imprisonment or a maximum prison sentence of 4 (four) years and a maximum of 20 (twenty) years and a maximum fine of Rp. 200,000,000.00 (two hundred million rupiah) and a maximum of Rp. 1,000,000,000.00 (one billion rupiah).

2. In the case of corruption crimes as referred to in paragraph (1) carried out under certain circumstances, the death penalty may be dropped.

Furthermore, the second reason is that the judge imposed the death penalty based on his conviction based on Article 24 paragraph (1) of the Constitution of the Republic of Indonesia year 1945 affirms that the power of the judiciary is an independent power to hold the judiciary to uphold the law and justice. If you look at the current conditions in which the indonesian people still have to deal with the outbreak of Covic-19 virus and the issue of Presidential Decree No. 12 of 2020 on the determination of Non-Natural Disasters spreadCorona Virus Disease 2019 (C ovic-19) As a National Disaster, it further strengthens article 2 of Law No. 31 of 1999 jo Law No. 20 of 2001 where perpetrators of corruption can be sentenced to death if under certain circumstances.

\section{Methodology}

This research uses primary ingredients and secondary ingredients to answer the problems that have been formulated. 


\section{Discussion}

\subsection{The Role of Society in Eradicating Corruption in Local Government}

The efforts of law enforcement officials in eradicating corruption crimes committed by regional heads seem to be entering a new round sheet, The growing number of provincial chiefs to the village government has felt the cold of prison, but the cases of hand-catching carried out by law enforcement officials seem to give fear to others, for example the legal snares that must be faced by some regents in Lampung province as regional heads, among them the bribery case of the head of the former regent of central Lampung, as well as the case of hand capture operation (OTT) carried out by the KPK to the head of the regent of north Lampung on Sunday 6/10/2019. The community itself has a role to play in assisting law enforcement officers in eradicating criminal corruption The role of the community itself is much needed considering that actually being victimized there is a society itself is very reasonable because the community is part of the country. Indications of a country's success in eradicating corruption can be judged on how good cooperation between law enforcement officers and society, because if the people themselves have a lack of care and are only silenced for the acts of corruption that they know then it can be certain that the country will be destroyed over time[6]

As long as corruption is rampant in all sectors of government, it will be very difficult to develop into a better regional system and be able to be competitive against other areas that have advanced in various sectors of government. The clean system of governance basically takes place in areas where people respect the law. Such local governments are also referred to as good governance. Good local government can only be built through a clean government with members of its bureaucratic staffing freed from the KKN[7]

The participation of the community itself has a clear legal basis as set out in article 108 paragraph 1 and paragraph 3 of Law No. 8 of 1981 on the Book of Criminal Proceedings Law namely: 1. Any person who experiences, sees, witnessed and or becomes a victim of an event that is a criminal offence has the right to file a report or complaint to the investigator and or investigator, whether oral or written; 2 . Every civil servant in order to carry out his/her duties knowing about the event that is a criminal offence must immediately report it to investigators or investigators [6]In addition to the article that has been mentioned the strength of the law on the basis of community involvement in the eradication of corruption crimes is further strengthened by Law No. 31 Year 1999 jo Law No. 20 of 2001 on The Eradication of Corruption Crimes in article 41 paragraph 2 mentioned that the participation of society in the eradication of Corruption Crimes can be realized in the form of:

a. The right to seek, obtain and provide information on suspected corruption.

b. The right to obtain services in the search for, obtain and provide information on the alleged corruption to law enforcement handling corruption cases.

c. The right to provide advice and opinions responsibly to law enforcement handling corruption crimes.

d. The right to obtain answers to questions about its reports given to law enforcement within a period of no later than 30 (thirty) days.

e. The right to obtain legal protection in the case of: Exercising its rights as referred to in letters a, b, and c; and required to be present in the investigation, investigation and court hearing as a whistleblower witness, witness or expert witness, in accordance with the provisions of the applicable laws and regulations[6] 
Appropriate measures are needed to prevent and eradicate corruption. The public is expected to have a strategic position within its movement space, but it is difficult to see some of the rules and policies made by the government in eradicating corruption not fully supporting it. Several acts of community participation in eradicating corruption, among others: First, the public plays a role in conveying information and reporting to the authorities if they know and see the crime of corruption. Second, the community plays a role in spreading the word on the issue of corruption that occurs as a form of low response of local law enforcement. All three communities can participate in overseeing the process of linking corruption cases[6]

In realizing a country that is clean from corruption is not something that can only be dreamed of if the whole community has a full awareness of avoiding corruption and helping law enforcement officials to eradicate corruption by performing their role as already ens found in the law.

\subsection{Judge's Ruling Sentencing For Corruption Perpetrators In Local Government}

The settlement of corruption cases in some indonesian areas is now a benchmark for the public in assessing the success or performance of law enforcement officers in creating a sense of justice in Indonesia. Corruption in Indonesia became the biggest contributor from the beginning of the destruction of the Indonesian nation in the economic sector so as to make people fall within the poverty line, as a country based on Indonesian law has actually had its own rules relating to corruption crimes such as the enactment of Law No. 31 of 1999 as amended to Law No. 20 of 2001 on the Eradication of Corruption Crimes which regulates all formulations of corruption crimes that are material and the pattern of settlement of cases is formal [8]Implementatively there are various rulings that by the judge sentencing criminals against the head of the region who commit corruption is carried out under the threat of funding that has been regulated in the specific criminal law of corruption crimes. This ruling will be a question for the public in general even if the decision the judge has made is inkracht. In the order of the system in the judicial world the existence of judges is considered very important, judges are officials who exercise judicial power, so the freedom of judges must always be in the corridors of independence of the institution of judicial power as specified in Article 3 of Law No. 48 of 2009 on the Judicial Commission which states that in carrying out its duties and functions, judges are obliged to maintain judicial independence [8]As an example of concrete efforts to eradicate corruption that is the verdict of the panel of judges against mustafa former regent lampung central which is in the sentence of 3 years less prison and required to pay a fine of Rp. 100 million subsider 3 months imprisonment.

The judge's decision to sentence the perpetrators of corruption offences by several regional heads is based on the law and the conviction of the judge without any intervention from any party, the judge's decision is based on the evidence and the facts revealed in the court. Sudikno Mertokusumo argued that the judge's ruling was a judge's statement, in his capacity as an officer authorized by law, in the form of a speech at trial and aimed at ending or resolving a case or a dispute between the parties [9]

In the law it has been explained about the freedom of judges in imposing a minimum or maximum sentence but the freedom stipulated must still be under the provisions of Article 12 of the Penal Code, imprisonment is life or for a certain time. (1) Imprisonment for a certain period of at least one day and at least fifteen years in a row. (2) A prison sentence for a certain period of time may be imposed for twenty consecutive years in the case of a crime for which the Judge may choose between the death penalty, a life sentence, and a prison sentence for a certain period of time, or between a life imprisonment and a prison sentence for a certain 
period of time; similarly, in the case of the fifteen-year limit exceeded for additional criminal reasons due to the same, repetition or because it is determined Article 52. Based on the above and based on the elements contained in each verdict, of course the Judge in sentencing should have complied with the sound of the indictment article in the sense that the judge is bound by the minimum limit and maximum limit so that the Judge is judged to have upheld the law appropriately and properly[9]The judge is allowed to freely determine the conviction that arises from him based on the evidence presented to the court but outside of that context the judge should not have any reason to influence it.

From the analysis, the juridical co-dependency to the judge's ruling that imposes a special minimum criminal in the case of corruption crimes under Article 197 paragraph 2 which is not fulfilled in paragraph (1) letter a, b, c, d, e, f, h, i, j, k and l of the article, in this case does not comply with the provisions of paragraph 1 letter $\mathrm{f}$ i.e. the article of legislation that is the basis of the criminal ity that is in violation of the provisions of Article 3 of UUPTPK: 1 . From the prestige of imprisonment as mentioned in Article 3 i.e. a minimum of 1 (one) year; 2. Without criminal fines as stipulated in Article 3 i.e. minimum criminal fine of Rp. 50.000.000,- (fifty millionrupiah). Thus the verdict Number: $2031 \mathrm{~K} / \mathrm{Pid}$.Sus/2011 resulted in null and void this also in accordance with the principle of Legality and the principle of universal minimum maximum special or special minimum principle / minimum means the Judge shall not impose a sentence lower than the minimum limit as set forth in the Law No. 31/1999 on the eradication of corruption crimes as changed and coupled with Law No. 20 of 2001 on the change of Law No. 31 of 1999 on eradicating corruption crimes [9]

Based on the description can be concluded that in giving a decision of the judge given the freedom to determine the weight or lightness of the punishment based on the evidence presented in the trial including in the freedom of the judge to give the death penalty to the head of the district who still dare to commit a criminal offence of corruption, the decisive verdict is an appropriate choice as proof to the public that the judge participated in the eradication of corruption.

\section{Conclusion}

Efforts to eradicate corruption carried out by law enforcement officials both from the Indonesian prosecutor' s office, the Corruption Eradication Commission and the authorities will not run effectively if not supported by all Indonesians, corruption will become more rampant freely if the public is only silenced against the abuse of authority committed by the leaders in the region, the discussion of the sentencing of perpetrators of corruption crimes until now is considered less effective as long as severe punishment has never been applied in the world of Indonesian criminal justice.

\section{Advice}

It is expected that the public will participate in supervising and reporting to the authorities in the event of corruption in the region, and it is also expected that the government may soon reform criminal law, especially on corruption crimes as proof that the government is supporting the efforts to eradicate corruption in the country. 


\section{References}

[1] Y. M. Deswantara, "Upaya Pemerintah Mewujudkan Pemerintahan yang Bebas dari Korupsi, Kolusi, dan Nepotisme," DiH J. Ilmu Huk., vol. 8, no. 16, 2012.

[2] E. N. Butarbutar, "Kebebasan Hakim Perdata dalam Penemuan Hukum dan Antinomi dalam Penerapannya," Mimb. Hukum-Fakultas Huk. Univ. Gadjah Mada, vol. 23, no. 1, pp. 61-76, 2011.

[3] M. Maryanto, "Pemberantasan Korupsi Sebagai Upaya Penegakan Hukum," CIVIS, vol. 2, no. 2/Juli, 2012.

[4] M. Hartana, "Efektivitas Penerapan E-Government dalam Pencegahan Tindak Pidana Korupsi di Lingkungan Pemerintahan Daerah," Panggung Huk. J. Perhimpun. Mhs. Huk. Indones. Cab. Drh. Istimewa Yogyakarta, vol. 1, no. 2, 2015.

[5] B. Waluyo, "Optimalisasi pemberantasan korupsi di indonesia," J. Yuridis, vol. 1, no. 2, pp. 162 169, 2017.

[6] M. Bunga, M. D. Maroa, A. Arief, and H. Djanggih, "Urgensi Peran Serta Masyarakat Dalam Upaya Pencegahan Dan Pemberantasan Tindak Pidana Korupsi," Law Reform, vol. 15, no. 1, pp. 85-97, 2019.

[7] R. Hamzah, "Implementasi Peran Serta Masyarakat dalam Pemberantasan Tindak Pidana Korupsi di Sumatera Barat," J. Ilm. Penegakan Huk., vol. 6, no. 1, pp. 1-13, 2019.

[8] A. Anshar and S. Suwito, "INFRA PETITA PUTUSAN PENGADILAN TINDAK PIDANA KORUPSI YANG MENEROBOS KETENTUAN PEMIDANAAN MINIMUM,” J. Yudisial, vol. 11, no. 2, pp. 151-170, 2018.

[9] G. G. A. Pah, E. Iriyanto, and L. Wulandari, "Analisis Yuridis Penjatuhan Pidana Oleh Hakim Dalam Tindak Pidana Korupsi (Putusan Nomor: 2031 K/Pid. Sus/2011),” Lentera Huk., vol. 1, no. 1, pp. 33-41, 2014. 